\author{
Marta CzYŻEWsKa \\ Uniwersytet Pedagogiczny w Krakowie, Polska - Pedagogical University of Krakow, Poland \\ Karolina Koziot \\ Uniwersytet Rzeszowski, Polska - University of Rzeszow, Poland
}

\title{
Diagnoza poziomu kompetencji przedsiębiorczych studentów wybranych uczelni według metodologii EntreComp
}

\section{Diagnosis of the Level of Entrepreneurial Competences of Students at Selected Universities According to the European Commission's EntreComp Methodology}

\begin{abstract}
Streszczenie: Przedsiębiorczość jest kompetencją o kluczowym znaczeniu dla rozwoju osobistego oraz działaniem polegającym na twórczym generowaniu pomysłów, opartym na identyfikacji i wykorzystywaniu nadarzających się okazji i szans rynkowych oraz realizacji tych pomysłów w podejmowanych przedsięwzięciach biznesowych. Celem artykułu jest: 1. diagnoza poziomu kompetencji przedsiębiorczych studentów Uniwersytetu Pedagogicznego w Krakowie oraz Uniwersytetu Rzeszowskiego przy wykorzystaniu metodologii EntreComp opracowanej dla Komisji Europejskiej oraz 2. identyfikacja zależności w poziomie kompetencji przedsiębiorczych, które różnicują badane osoby pod względem następujących cech: demograficznych, statusu materialnego, miejsca zamieszkania, sytuacji zawodowej oraz długości okresu studiowania i kierunku kształcenia. Metodologia zalecana przez Komisję Europejską do wykorzystywania w procesach kształcenia przedsiębiorczości stanowi ramy dla kształcenia kompetencji przedsiębiorczych uznawanych przez UE za kluczowe. Realizacji celu pracy posłużyły badania ankietowe, które przeprowadzono w maju i czerwcu 2019 r. na próbie 106 studentów. Badanie autorek uzupełnia w pewnym stopniu lukę badawczą traktując przedsiębiorczość jako nurt koncentrujący się na kompetencjach przedsiębiorczych, podkreślanych przez organy UE jako kluczowe. Odrębny nurt równie popularny w literaturze bada przedsiębiorczość jako fenomen koncentrujący się na działaniach przedsiębiorczych.
\end{abstract}

\begin{abstract}
Entrepreneurship is a key competence for personal development and an activity consisting in the creative generation of ideas, based on the identification and use of opportunities and market niches, and the implementation of these ideas by undertaking business ventures. The purpose of the article is: 1. the diagnosis of the level of entrepreneurial competences of students of the Pedagogical University of Krakow and the University of Rzeszów using the EntreComp methodology developed for the European Commission; and 2. the identification of relationships in the level of entrepreneurial competences that differentiate the surveyed people in terms of the following features: demographic, material status, place of residence, professional situation, length of study period and field of study. The methodology
\end{abstract}


recommended by the European Commission for use in entrepreneurship education processes provides a framework for the training of entrepreneurial competences recognised by the $\mathrm{EU}$ as key competences. The purpose of the article was achieved by a survey conducted in May and June 2019 on a sample of 106 students. The authors' study fills the research gap to some extent by approaching entrepreneurship as a trend focusing on entrepreneurial competences highlighted by key EU bodies. A separate trend, equally popular in literature, studies entrepreneurship as a phenomenon focusing on entrepreneurial activities.

Słowa kluczowe: edukacja przedsiębiorczości; kompetencje przedsiębiorcze; postawy przedsiębiorcze; przedsiębiorczość

Keywords: entrepreneurial attitudes; entrepreneurial competences; entrepreneurship; entrepreneurship education

Otrzymano: 30 października 2019

Received: 30 October 2019

Zaakceptowano: 23 marca 2020

Accepted: 23 March 2020

\section{Sugerowana cytacja/Suggested citation:}

Czyżewska, M., Kozioł, K., (2020) Diagnoza poziomu kompetencji przedsiębiorczych studentów wybranych uczelni według metodologii EntreComp. Przedsiębiorczość - Edukacja [Entrepreneurship Education ], 16(1), 45-61. doi: 10.24917/20833296.161.4

\section{Wstęp}

Literatura przedmiotu bogata jest w definicje przedsiębiorczości, wskazuje ona jednak głównie na dwa nurty: psychologiczny i ekonomiczny. Pierwszy nurt traktuje przedsiębiorczość jako cechę osobowości jednostki, zdolności, twórcze postawy, a nawet popęd twórczy (Kapusta, 2006: 20-22). Nurt ekonomiczny traktuje przedsiębiorczość jako proces, w ramach którego można w mniej lub bardziej efektywny sposób wykorzystać nadarzające się okazje.

Kwestią dyskusyjną nadal pozostaje ustalenie, czy przedsiębiorczość jest wrodzoną predyspozycją psychiczną, czy raczej postawą wykształconą w procesie edukacji, czyli ciągłego zdobywania wiedzy - podnoszenia kompetencji oraz kwalifikacji danej osoby.

Przedsiębiorczość jest cechą obecnie bardzo wysoko cenioną w kontekście rozwoju osobistego. Jest ona traktowana jako źródło wszelkiej innowacyjności (Bieniok, 2016: 160-165) oraz warunek do budowania innowacyjnej i konkurencyjnej gospodarki. To złożona kompetencja o bardzo wysokiej randze w gospodarce rynkowej, szczególnie w sektorze biznesowym (Wyrzykowska, 2012: 25).

Celem niniejszego artykułu jest diagnoza poziomu kompetencji przedsiębiorczych studentów Uniwersytetu Pedagogicznego w Krakowie oraz Uniwersytetu Rzeszowskiego przy wykorzystaniu metodologii EntreComp opracowanej na zlecenie Komisji Europejskiej, a także identyfikacja zależności w poziomie kompetencji przedsiębiorczych, które różnicują badane osoby pod względem: cech demograficznych, statusu materialnego, miejsca zamieszkania, sytuacji zawodowej oraz długości okresu studiowania i kierunku kształcenia. Metodologia Komisji Europejskiej stanowi ramy dla kształcenia kompetencji przedsiębiorczych uznawanych przez Unię Europejską za kompetencje kluczowe, niezbędne dla pracodawców i sprzyjające rozwijaniu nowych przedsięwzięć biznesowych. 
Autorki przeprowadziły badania ankietowe na przełomie maja i czerwca 2019 r. na próbie 106 studentów Uniwersytetu Pedagogicznego w Krakowie oraz Uniwersytetu Rzeszowskiego. Badania pozwoliły zdiagnozować poziom kompetencji przedsiębiorczych wśród studentów na podstawie ewaluacji własnych kompetencji studentów. Pytania $\mathrm{w}$ kwestionariuszu ankiety - zgodnie $\mathrm{z}$ metodologią - zostały pogrupowane w trzech obszarach: idee i możliwości (ang. ideas and opportunities), zasoby (ang. resources) oraz działanie (ang. into action).

\section{Przedsiębiorczość a kompetencje przedsiębiorcze}

Przedsiębiorczość nie jest jednorodnym fenomenem, łatwym do zdefiniowania i opisania, lecz zjawiskiem wielowymiarowym o znaczącej roli dla procesów społeczno-gospodarczych. Według P. Druckera, nauka o przedsiębiorczości jest środkiem do osiągnięcia celu, a to, co stanowi naukę, jest w znacznym stopniu określone przez cel, w jakim takie działania są prowadzone, tzn. przez praktykę (Drucker, 1992: 8).

Przedsiębiorczość można rozpatrywać w kontekście zjawiska ekonomicznego, społecznego, jak również w kontekście działań związanych z zarządzaniem przedsięwzięciami biznesowymi (Glinka, Gudkova, 2011). Definicje przedsiębiorczości w literaturze przedmiotu odnoszą się do:

- rynku, czyli działań przedsiębiorczych w gospodarce,

- osobowości, tj. cech osobowych przedsiębiorców,

- czynności menedżerskich, czyli specyficznego sposobu zarządzania,

- indywidualnego przedsiębiorcy (Wach, 2013: 246-257; 2015: 24-36).

Z kolei T. Rachwał przedsiębiorczość określa jako zespół cech osobowości człowieka, takich jak: aktywność, zapał do pracy, inicjatywa, kreatywność, podzielność uwagi, zdolność do koncentracji, pewność siebie, samodyscyplina, skłonność do wyważonego ryzyka i brania odpowiedzialności za siebie i innych oraz posiadana intuicja i umiejętności (np. w zakresie komunikacji interpersonalnej, kierowania sobą i innymi, podejmowania decyzji, oszacowania nakładów potrzebnych do realizacji danego przedsięwzięcia (Rachwal, 2004).

Przedsiębiorczość zaliczana jest do głównych kompetencji, zwanych kluczowymi, zarówno w odniesieniu do cech osoby, która je posiada, jak i w odniesieniu do działań organizacji. W szerokim ujęciu za kompetencje można przyjąć wszelkie cechy i uprawnienia pracowników oraz organizacji, które są wykorzystywane i rozwijane w procesie pracy i służą osiąganiu celów organizacji oraz spójnych z nimi osobistych celów pracowników (Moczydłowska, 2008). Koncepcja kompetencji przedsiębiorczych została zapoczątkowana przez R.A. Boyatzisa (Boyatzis, 1982). Na podstawie badań prowadzonych w przedsiębiorstwach stworzył on model kompetencji, którymi powinni odznaczać się skuteczni menedżerowie.

Nad opracowaniem koncepcji kompetencji przedsiębiorczych pochylił się również T. Boyles (Boyles, 2012), który wskazał konkretne kompetencje odnoszące się do kompetencji przedsiębiorczych z podziałem na:

- kompetencje poznawcze,

- kompetencje społeczne,

- kompetencje zorientowane na działanie oraz grupę kompetencji XXI w. 
J. Moczydłowska również stworzyła model kompetencji przedsiębiorczych, warunkujących sukces osoby chcącej realizować się zawodowo. Do najważniejszych kompetencji przedsiębiorczych, uwzględniających konkretne cechy, umiejętności i wynikające z nich zachowania autorka zaliczyła:

- umiejętność podejmowania decyzji,

- innowacyjność i twórczość,

- otwartość na zmiany,

- odporność na trudne sytuacje,

- komunikatywność,

- wysoki poziom dojrzałości emocjonalnej,

- przywództwo i współpracę,

- samoświadomość, pozytywną samoocenę,

- motywację,

- wiedzę biznesową (Moczydłowska, 2008: 390).

Kompetencje przedsiębiorcze obejmują wiedzę, umiejętności i postawy niezbędne dla skuteczności i efektywności działań przedsiębiorczych, związanych z podejmowaniem i realizacją przedsięwzięć umożliwiających osiąganie określonych wartości w warunkach niepewności i ryzyka (Bojewska, 2002).

Badania D. Piróg (Piróg, 2015: 366) wskazują, że termin „kompetencja” ma wiele znaczeń i choć w literaturze naukowej pojawił się niedawno, stał się przedmiotem badań wielu specjalistów, m.in. z zakresu pedagogiki pracy, polityki społecznej, ekonomii, socjologii, psychologii oraz dydaktyki szkoły wyższej.

S. Mitchelmore i J. Rowley (Mitchelmore, Rowley, 2010) oraz D. Piróg (2015) sklasyfikowali kompetencje przedsiębiorcze, dzieląc je na trzy główne obszary: osobowościowe, behawioralne i menedżerskie (tabela 1).

Tabela 1. Klasyfikacja kompetencji z zakresu przedsiębiorczości

\begin{tabular}{|l|l|l|}
\hline \multicolumn{2}{|c|}{ Kompetencje } \\
\hline osobowościowe (społeczne) & behawioralne (osobiste) & \multicolumn{1}{c|}{ menedżerskie } \\
\hline - pewność siebie & - asertywność & - komunikacja \\
- poczucie umiejscowienia & - gotowość do & interpersonalna \\
kontroli & podejmowania ryzyka & - umiejętność formułowania \\
- radzenie sobie & - inicjatywność & celów \\
z trudnościami & - kreatywność & - umiejętność \\
- tolerancja & - potrzeba autonomii & komunikowania się \\
- troska o wysoką jakość & - umiejętność poszukiwania & - umiejętność perswazji \\
- umiejętność & i wykorzystywania szans & - umiejętność poszukiwania \\
autoprezentacji & - umiejętność podejmowania & informacji \\
- umiejętność samooceny & ryzyka & - umiejętność rozwiązywania \\
& - witalność i energia & problemów \\
& - wola sukcesu & - umiejętność \\
& - wytrwałość & systematycznego \\
& & planowania \\
& & obycie techniczne \\
\hline
\end{tabular}

Źródło: na podstawie: Mitchelmore, Rowley (2010), Piróg (2015) 
W Europejskich ramach kompetencji w zakresie przedsiębiorczości przedsiębiorczość uznawana jest za kompetencję przekrojową, znajdującą zastosowanie we wszystkich sferach życia: od wspierania rozwoju osobistego, przez aktywny udział w życiu społecznym, po (ponowne) wejście na rynek pracy jako pracownik lub osoba samozatrudniona i podejmowanie działalności (kulturalnej, społecznej lub komercyjnej) (EntreComp, 2016).

\section{Metody badawcze oraz wyniki przeprowadzonych badań}

Dla realizacji postawionych w artykule celów autorki przeprowadziły badania empiryczne wśród studentów Uniwersytetu Pedagogicznego w Krakowie oraz Uniwersytetu Rzeszowskiego na próbie badawczej 106 osób studiujących w trybie stacjonarnym i niestacjonarnym.

W artykule wykorzystano metodologię EntreComp opracowaną przy użyciu metody mieszanej, złożonej z kompleksowego przeglądu literatury akademickiej i dogłębnej analizy studiów przypadków oraz zestawu iteracyjnych konsultacji z wieloma zainteresowanymi stronami (Komisja Europejska, 2020).

Poziom kompetencji przedsiębiorczych bada się w obszarach: idee i możliwości (ang. ideas and opportunities), zasoby (ang. resources) oraz działanie (ang. into action). Każdy z obszarów opisuje po kilkanaście kompetencji cząstkowych, które można mierzyć w skali od 1 do 8 według czterech poziomów zaawansowania zilustrowanych w tabeli 2 .

Tabela 2. Poziomy kompetencji w EntreComp

\begin{tabular}{|c|c|c|c|c|c|c|c|}
\hline \multicolumn{2}{|c|}{ Podstawowy } & \multicolumn{2}{|c|}{$\begin{array}{c}\text { Średnio- } \\
\text { zaawansowany }\end{array}$} & \multicolumn{2}{|c|}{ Zaawansowany } & \multicolumn{2}{|c|}{ Ekspercki } \\
\hline 1 & 2 & 3 & 4 & 5 & 6 & 7 & 8 \\
\hline \multicolumn{2}{|c|}{$\begin{array}{c}\text { poleganie na } \\
\text { wsparciu od innych }\end{array}$} & \multicolumn{2}{|c|}{$\begin{array}{c}\text { budowanie } \\
\text { niezależności }\end{array}$} & \multicolumn{2}{|c|}{$\begin{array}{c}\text { przyjmowanie } \\
\text { odpowiedzialności }\end{array}$} & \multicolumn{2}{|c|}{$\begin{array}{c}\text { inicjowanie przemian, } \\
\text { innowacji i wzrostu }\end{array}$} \\
\hline $\begin{array}{l}\text { Pod bez- } \\
\text { pośrednim } \\
\text { nadzorem }\end{array}$ & $\begin{array}{l}\text { Przy ogra- } \\
\text { niczonym } \\
\text { wsparciu } \\
\text { od innych, } \\
\text { trochę } \\
\text { niezależnie } \\
\text { i razem } \\
\text { z innymi }\end{array}$ & $\begin{array}{l}\text { Samodziel- } \\
\text { nie i razem } \\
\text { z rówieśni- } \\
\text { kami/ } \\
\text { partnerami }\end{array}$ & \begin{tabular}{|l} 
Przyjmo- \\
wanie \\
i dzielenie \\
(w pewnym \\
zakresie) \\
odpowie- \\
dzialności
\end{tabular} & $\begin{array}{l}\text { Przy } \\
\text { pewnym } \\
\text { wsparciu } \\
\text { przywódcy } \\
\text { i razem } \\
\text { z innymi }\end{array}$ & $\begin{array}{l}\text { Przyjmo- } \\
\text { wanie } \\
\text { odpowie- } \\
\text { dzialności } \\
\text { za podej- } \\
\text { mowanie } \\
\text { decyzji } \\
\text { i w pracy } \\
\text { z innymi }\end{array}$ & $\begin{array}{l}\text { Przyjmo- } \\
\text { wanie } \\
\text { odpowie- } \\
\text { dzialności } \\
\text { za współ- } \\
\text { tworzenie } \\
\text { złożonych } \\
\text { zadań } \\
\text { w kon- } \\
\text { kretnym } \\
\text { obszarze }\end{array}$ & $\begin{array}{l}\text { Znaczny } \\
\text { wkład } \\
\text { w rozwój } \\
\text { konkret- } \\
\text { nego } \\
\text { obszaru }\end{array}$ \\
\hline Odkrywaj & Eksploruj & $\begin{array}{l}\text { Ekspery- } \\
\text { mentuj }\end{array}$ & Odważ się & Ulepszaj & Wzmacniaj & Rozwiń & Przekształć \\
\hline
\end{tabular}

Źródło: opracowanie na podstawie: EntreComp (2016: 23)

W kwestionariuszu ankiety skierowanej do badanych studentów drogą mailową opracowanym w formularzu Google zawarto pytania pozwalające respondentom dokonać wnikliwej samoewaluacji poszczególnych kompetencji przedsiębiorczych w obszarach: kreowania pomysłów, gospodarowania zasobami oraz podejmowania działań, według kryteriów zaprezentowanych w tabeli 3. 
Tabela 3. Klasyfikacja obszarów oraz wchodzących w ich skład badanych kompetencji przedsiębiorczych według metodologii EntreComp

\begin{tabular}{|c|c|c|c|}
\hline Obszar & Kompetencje & Wyjaśnienie & Kryteria samooceny \\
\hline \multirow{5}{*}{ 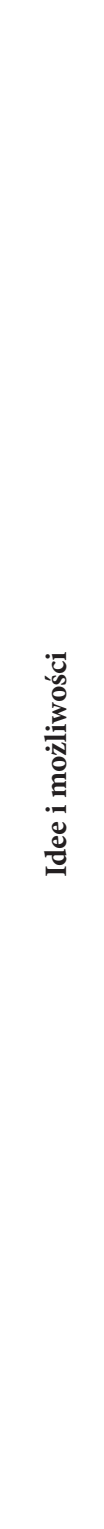 } & $\begin{array}{l}\text { Dostrzeganie } \\
\text { możliwości }\end{array}$ & $\begin{array}{l}\text { Zidentyfikuj i wykorzystaj } \\
\text { możliwości tworzenia wartości } \\
\text { przez eksplorowanie społecznego, } \\
\text { kulturalnego i ekonomicznego } \\
\text { otoczenia. Zidentyfikuj potrzeby } \\
\text { i wyzwania, na które trzeba } \\
\text { odpowiedzieć. Zawrzyj nowe } \\
\text { znajomości i złóż w całość } \\
\text { „rozrzucone elementy układanki”, } \\
\text { by umożliwiać tworzenie } \\
\text { wartości }\end{array}$ & $\begin{array}{l}\text { 1. Identyfikowanie i ocena } \\
\text { szans rynkowych, } \\
\text { możliwości tworzenia } \\
\text { wartości dla klienta } \\
\text { 2. Koncentracja na } \\
\text { wyzwaniach i problemach } \\
\text { 3. Odkrywanie potrzeb } \\
\text { rynkowych } \\
\text { 4. Analiza kontekstu }\end{array}$ \\
\hline & Kreatywność & $\begin{array}{l}\text { Rozwijaj pomysły i możliwości } \\
\text { tworzenia wartości, w tym lepsze } \\
\text { nowe rozwiązania w odpowiedzi } \\
\text { na wyzwania. Przeglądaj } \\
\text { i eksperymentuj z innowacyjnym } \\
\text { podejściem. Połącz wiedzę } \\
\text { z zasobami, aby osiągać } \\
\text { wartościowe rezultaty }\end{array}$ & $\begin{array}{l}\text { 1. Ciekawość i otwartość } \\
\text { 2. Rozwijanie pomysłów } \\
\text { 3. Definiowanie problemów } \\
\text { 4. Projektowanie wartości } \\
\text { 5. Bycie innowacyjnym }\end{array}$ \\
\hline & Tworzenie wizji & $\begin{array}{l}\text { Wyobraź sobie przyszłość. } \\
\text { Rozwijaj wizję, przekuj pomysł } \\
\text { w działanie. Wyobraź sobie } \\
\text { przyszłe scenariusze, aby } \\
\text { wspierać wysiłki planowania } \\
\text { i działań }\end{array}$ & $\begin{array}{l}\text { 1. Wizja przyszłości } \\
\text { 2. Myślenie strategiczne } \\
\text { 3. Dążenie do realizacji wizji }\end{array}$ \\
\hline & Ocena pomysłów & $\begin{array}{l}\text { Oszacuj, co stanowi wartość } \\
\text { w aspekcie społecznym, } \\
\text { kulturalnym i ekonomicznym. } \\
\text { Rozpoznaj potencjał pomysłu na } \\
\text { tworzenie wartości i określ do } \\
\text { tego odpowiednie sposoby }\end{array}$ & $\begin{array}{l}\text { 1. Ocena pomysłów } \\
\text { 2. Dzielenie się i ochrona } \\
\text { pomysłów }\end{array}$ \\
\hline & $\begin{array}{l}\text { Etyka } \\
\text { i zrównoważone } \\
\text { myślenie }\end{array}$ & $\begin{array}{l}\text { Oceń wpływ pomysłów } \\
\text { tworzących wartość i rezultaty } \\
\text { przedsiębiorczego działania } \\
\text { na grupę docelowá, rynek, } \\
\text { społeczeństwo i środowisko. } \\
\text { Zastanów się, jakie są } \\
\text { długoterminowe cele społeczne, } \\
\text { ekonomiczne i w zakresie } \\
\text { zrównoważonego rozwoju, } \\
\text { a także, jaki jest planowany } \\
\text { przebieg działań. Działaj } \\
\text { odpowiedzialnie }\end{array}$ & $\begin{array}{l}\text { 1. Zachowanie etyczne } \\
\text { 2. Myślenie w sposób } \\
\text { zrównoważony } \\
\text { 3. Szacowanie wpływu } \\
\text { 4. Bycie odpowiedzialnym }\end{array}$ \\
\hline
\end{tabular}




\begin{tabular}{|c|c|c|c|}
\hline Obszar & Kompetencje & Wyjaśnienie & Kryteria samooceny \\
\hline \multirow{5}{*}{$\begin{array}{l}\hat{0} \\
\text { Dे } \\
\text { N } \\
\text { N }\end{array}$} & $\begin{array}{l}\text { Samoświadomość } \\
\text { i poczucie własnej } \\
\text { skuteczności }\end{array}$ & $\begin{array}{l}\text { Zastanów się nad swoimi } \\
\text { potrzebami, aspiracjami } \\
\text { i chęciami w krótkim, średnim } \\
\text { i długim okresie. Zidentyfikuj } \\
\text { i oceń swoje indywidualne } \\
\text { oraz grupowe mocne i słabe } \\
\text { strony. Uwierz w swoje } \\
\text { zdolności do wpływania na bieg } \\
\text { wydarzeń pomimo niepewności, } \\
\text { niepowodzeń i chwilowych } \\
\text { porażek }\end{array}$ & $\begin{array}{l}\text { 1. Podążanie za aspiracjami } \\
\text { 2. Identyfikacja mocnych } \\
\text { i słabych stron } \\
\text { 3. Wiara we własne } \\
\text { możliwości } \\
\text { 4. Kształtowanie przyszłości }\end{array}$ \\
\hline & $\begin{array}{l}\text { Motywacja } \\
\text { i wytrwałość }\end{array}$ & $\begin{array}{l}\text { Bądź zdeterminowany, aby } \\
\text { przekuwać pomysły w działanie } \\
\text { w celu zaspokajania potrzeby } \\
\text { osiągnięć. Bądź przygotowany } \\
\text { na cierpliwe i wytrwałe } \\
\text { dążenie do osiągnięcia swojego } \\
\text { indywidualnego lub grupowego } \\
\text { celu. Bądź odporny na presję, } \\
\text { przeciwności losu i chwilowe } \\
\text { niepowodzenia }\end{array}$ & $\begin{array}{l}\text { 1. Napędzanie się } \\
\text { i motywacja } \\
\text { 2. Bycie zdeterminowanym } \\
\text { 3. Skupienie się na tym, } \\
\text { co motywuje } \\
\text { 4. Bycie odpornym } \\
\text { 5. Niepoddawanie się }\end{array}$ \\
\hline & $\begin{array}{l}\text { Mobilizowanie } \\
\text { zasobów }\end{array}$ & \begin{tabular}{|l} 
Uzyskaj zasoby materialne, \\
niematerialne i cyfrowe \\
potrzebne do przekuwania \\
pomysłów w działanie i zarządzaj \\
tymi zasobami. Wykorzystaj \\
maksymalnie ograniczone zasoby. \\
Uzyskaj kompetencje potrzebne \\
na poszczególnych etapach, \\
włączając w to kompetencje: \\
techniczne, prawne, podatkowe \\
i cyfrowe (np. przez odpowiednie \\
partnerstwa, sieć współpracy, \\
outsourcing i crowdsourcing) \\
i zarządzaj tymi kompetencjami \\
\end{tabular} & $\begin{array}{l}\text { 1. Zarządzanie zasobami } \\
\text { (materialnymi } \\
\text { i niematerialnymi) } \\
\text { 2. Odpowiedzialne } \\
\text { korzystanie z zasobów } \\
\text { 3. Najlepsze wykorzystanie } \\
\text { czasu } \\
\text { 4. Pozyskiwanie wsparcia }\end{array}$ \\
\hline & $\begin{array}{l}\text { Kompetencje } \\
\text { w obszarze } \\
\text { finansów } \\
\text { i ekonomii }\end{array}$ & $\begin{array}{l}\text { Oszacuj koszt przekucia pomysłu } \\
\text { w działanie tworzące wartość. } \\
\text { Określ czas i budżet. Zarządzaj } \\
\text { finansami, aby upewnić się, że } \\
\text { działanie tworzące wartość może } \\
\text { być długoterminowe }\end{array}$ & $\begin{array}{l}\text { 1. Rozumienie zagadnień } \\
\text { ekonomicznych } \\
\text { i finansowych } \\
\text { 2. Budżetowanie } \\
\text { 3. Pozyskiwanie finansowania } \\
\text { 4. Rozumienie } \\
\text { zagadnień związanych } \\
\text { z opodatkowaniem }\end{array}$ \\
\hline & $\begin{array}{l}\text { Mobilizowanie } \\
\text { innych }\end{array}$ & $\begin{array}{l}\text { Inspiruj i zaciekawiaj } \\
\text { odpowiednich interesariuszy. } \\
\text { Uzyskaj wsparcie potrzebne } \\
\text { do osiągnięcia wartościowych } \\
\text { rezultatów. Wykaż się efektywną } \\
\text { komunikacją, perswazją, } \\
\text { umiejętnościami negocjacyjnymi } \\
\text { i przywódczymi }\end{array}$ & $\begin{array}{l}\text { 1. Inspirowanie siebie } \\
\text { i innych } \\
\text { 2. Perswazja } \\
\text { 3. Efektywna komunikacja } \\
\text { 4. Efektywne korzystanie } \\
\text { z mediów }\end{array}$ \\
\hline
\end{tabular}




\begin{tabular}{|c|c|c|c|}
\hline Obszar & Kompetencje & Wyjaśnienie & Kryteria samooceny \\
\hline \multirow{5}{*}{ 䔍 } & $\begin{array}{l}\text { Przejmowanie } \\
\text { inicjatywy }\end{array}$ & $\begin{array}{l}\text { Inicjuj procesy tworzenia } \\
\text { wartości, podejmuj wyzwania. } \\
\text { Działaj i pracuj niezależnie } \\
\text { w osiąganiu celów, trzymaj się } \\
\text { ustalonych planów }\end{array}$ & $\begin{array}{l}\text { 1. Przyjmowanie } \\
\text { odpowiedzialności } \\
\text { 2. Samodzielność w realizacji } \\
\text { zadań } \\
\text { 3. Podejmowania działania }\end{array}$ \\
\hline & $\begin{array}{l}\text { Planowanie } \\
\text { i zarządzanie }\end{array}$ & $\begin{array}{l}\text { Ustal długo-, średnio- } \\
\text { i krótkoterminowe cele. } \\
\text { Zdefiniuj priorytety i plany } \\
\text { działania. Przystosowuj się } \\
\text { do nieprzewidzianych zmian }\end{array}$ & $\begin{array}{l}\text { 1. Definiowanie celów } \\
\text { 2. Planowanie i organizacja } \\
\text { 3. Rozwijanie } \\
\text { „zrównoważonych” } \\
\text { biznesplanów } \\
\text { 4. Definiowanie priorytetów } \\
\text { 5. Monitorowanie postępów } \\
\text { 6. Elastyczność i adaptacja } \\
\text { do zmian }\end{array}$ \\
\hline & $\begin{array}{l}\text { Radzenie sobie } \\
\text { z niejednoznaczno- } \\
\text { ścią, niepewnością } \\
\text { i ryzykiem }\end{array}$ & $\begin{array}{l}\text { Podejmuj decyzje w warunkach } \\
\text { niepewności, niepełnej lub } \\
\text { niejednoznacznej informacji albo } \\
\text { w warunkach ryzyka. W obszarze } \\
\text { tworzenia wartości zaprojektuj } \\
\text { sposoby testowania pomysłów } \\
\text { i prototypu na wczesnych } \\
\text { stadiach rozwoju w celu } \\
\text { ograniczenia ryzyka }\end{array}$ & $\begin{array}{l}\text { 1. Radzenie sobie } \\
\text { z niepewnością } \\
\text { i niejednoznacznością } \\
\text { 2. Kalkulowanie ryzyka } \\
\text { 3. Zarządzanie ryzykiem }\end{array}$ \\
\hline & $\begin{array}{l}\text { Umiejętność } \\
\text { współpracy } \\
\text { w zespole }\end{array}$ & $\begin{array}{l}\text { Współpracuj z innymi } \\
\text { w rozwijaniu pomysłów } \\
\text { i przekuwaniu ich w działanie. } \\
\text { Twórz sieć współpracy. } \\
\text { Rozwiązuj konflikty } \\
\text { i konstruktywnie stawiaj czoła } \\
\text { konkurencji, kiedy to konieczne }\end{array}$ & $\begin{array}{l}\text { 1. Akceptacja różnorodności } \\
\text { 2. Rozwijanie inteligencji } \\
\text { emocjonalnej } \\
\text { 3. Aktywne słuchanie } \\
\text { 4. Budowanie zespołu } \\
\text { 5. Współpraca w zespole } \\
\text { 6. Rozszerzanie sieci } \\
\text { współpracy }\end{array}$ \\
\hline & $\begin{array}{l}\text { Ciągłe uczenie } \\
\text { się przez } \\
\text { doświadczenie }\end{array}$ & $\begin{array}{l}\text { Traktuj dowolną inicjatywę } \\
\text { do tworzenia wartości jako } \\
\text { szansę zdobywania wiedzy. } \\
\text { Ucz się z innymi, włącznie } \\
\text { z rówieśnikami i mentorami. } \\
\text { Wyciągaj wnioski i ucz się } \\
\text { zarówno na sukcesach, jak } \\
\text { i na porażkach (swoich i innych) }\end{array}$ & $\begin{array}{l}\text { 1. Uczenie się na podstawie } \\
\text { doświadczeń innych } \\
\text { i własnych } \\
\text { 2. Uczenie uczenia się } \\
\text { 3. Uczenie się przez } \\
\text { doświadczenia }\end{array}$ \\
\hline
\end{tabular}

Źródło: opracowanie na podstawie: EntreComp (2016: 23-35)

\section{Charakterystyka badanej grupy}

W badaniach wzięło udział 88\% kobiet (93 osoby) i 12\% mężczyzn (13 osób). 61\% badanych stanowili studenci studiów pierwszego stopnia, 38\% respondentów - studenci drugiego stopnia, $1 \%$ - studenci jednolitych studiów magisterskich. $62 \%$ osób studiowało na pierwszym roku, $23 \%$ - na trzecim, $11 \%$ - na czwartym i $4 \%$ - na piątym roku studiów. 69\% stanowili studenci studiujący w trybie stacjonarnym, zaś $31 \%$ - w trybie niestacjonarnym. Jeśli chodzi o studiowany kierunek, dominowały osoby studiujące 
administrację (75\%), pozostałą część (25\%) stanowili studenci ekonomii. Uniwersytet Pedagogiczny w Krakowie reprezentowało 76\% respondentów, zaś Uniwersytet Rzeszowski - 24\%. Przeważająca większość respondentów (58\%) zamieszkiwała tereny wiejskie, drugą najliczniejszą grupę stanowili mieszkańcy miast powyżej 100 tys. mieszkańców (18\%) (rycina 1).

$68 \%$ badanych zamieszkiwało na stałe w województwie małopolskim, zaś $25 \%$ - w województwie podkarpackim. Pozostałe $4 \%$ to mieszkańcy województwa lubelskiego, a 3\% województwa świętokrzyskiego.

Zdecydowana większość badanych oceniła swój status materialny co najmniej dobrze (73\%) (rycina 2).

Rycina 1. Miejsce zamieszkania ankietowanych

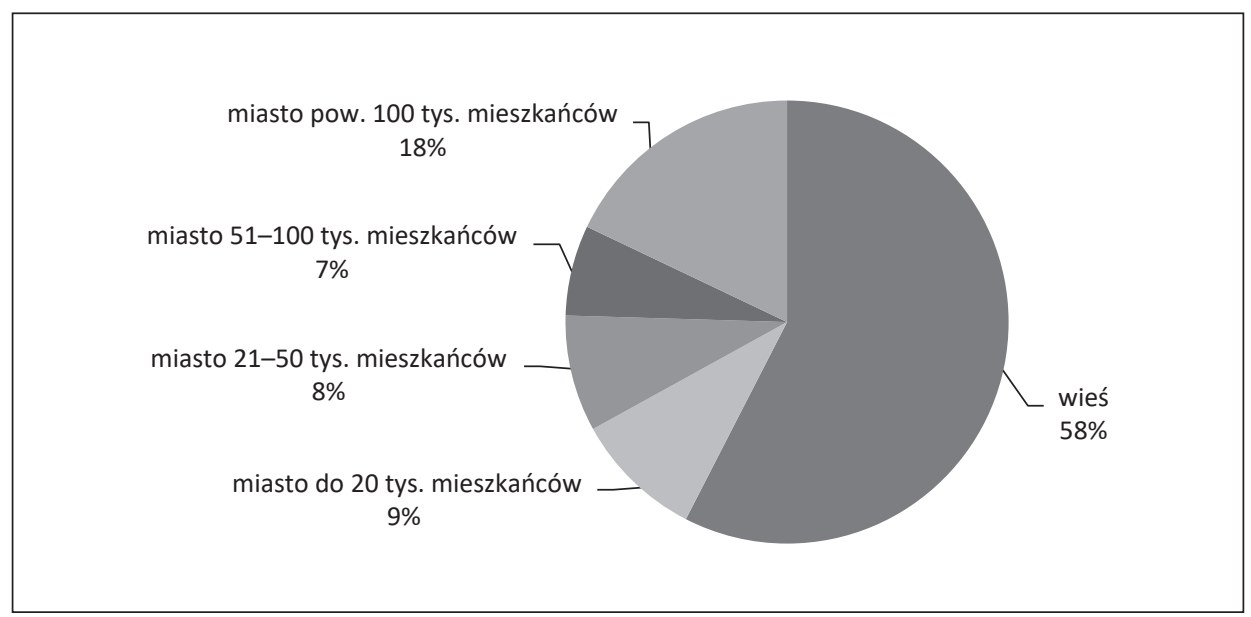

Źródło: opracowanie własne na podstawie badań

Rycina 2. Ocena statusu materialnego ankietowanych

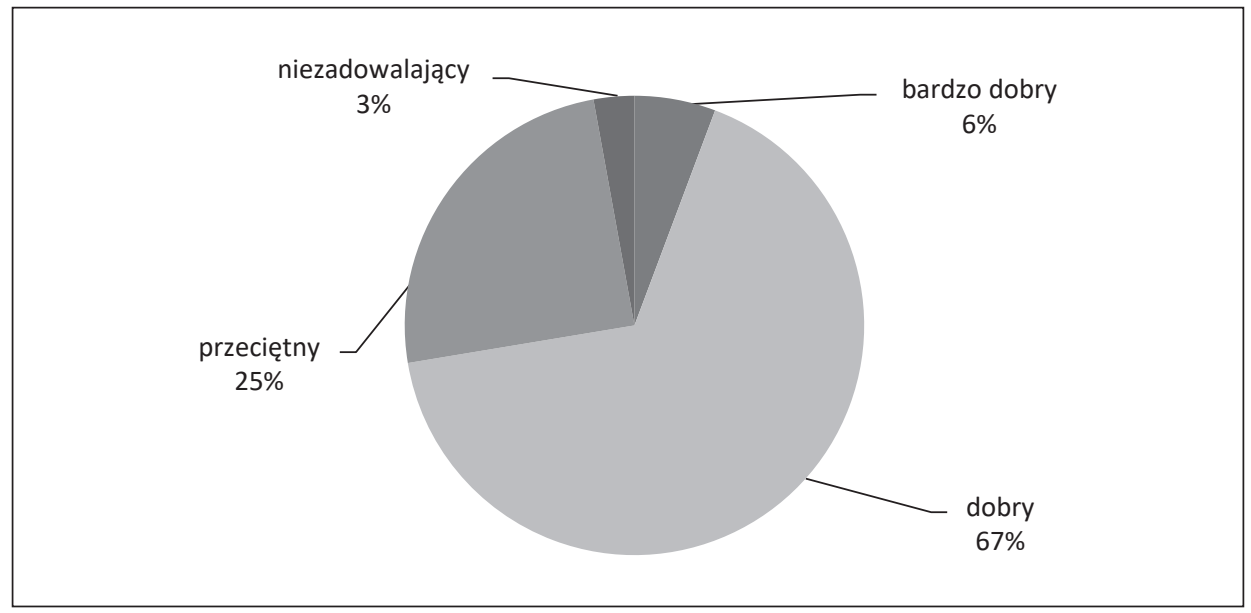

Źródło: opracowanie własne na podstawie badań 
Diagnoza kompetencji badanych w obszarze „idee i możliwości”

Według metodologii EntreComp, na kompetencje w obszarze „idee i możliwości” składają się kompetencje „cząstkowe” dotyczące umiejętności: analizy otoczenia, identyfikacji potrzeb rynku, rozwiązywania problemów, rozwijania pomysłów, projektowania nowych rozwiązań itp. (rycina 1). W tym obszarze badani dokonali samoewaluacji swoich kompetencji, wybierając odpowiedź najlepiej odzwierciedlającą ich poziom w skali od 1 do 8 (w przypadku większości pytań; tabela 4). Średnie oceny poszczególnych kompetencji cząstkowych oscylowały między 2,4 (bycie odpowiedzialnym) a 4,2 (ocena szans i tworzenie wartości), co odzwierciedlało poziom podstawowy lub średniozaawansowany kompetencji przedsiębiorczych (rycina 3).

Szczegółowe wyniki poszczególnych kryteriów diagnozujących kompetencje badanych w obszarze „idee i możliwości” zaprezentowano w tabeli 4.

Rycina 3. Idee i możliwości ich realizacji według badanych

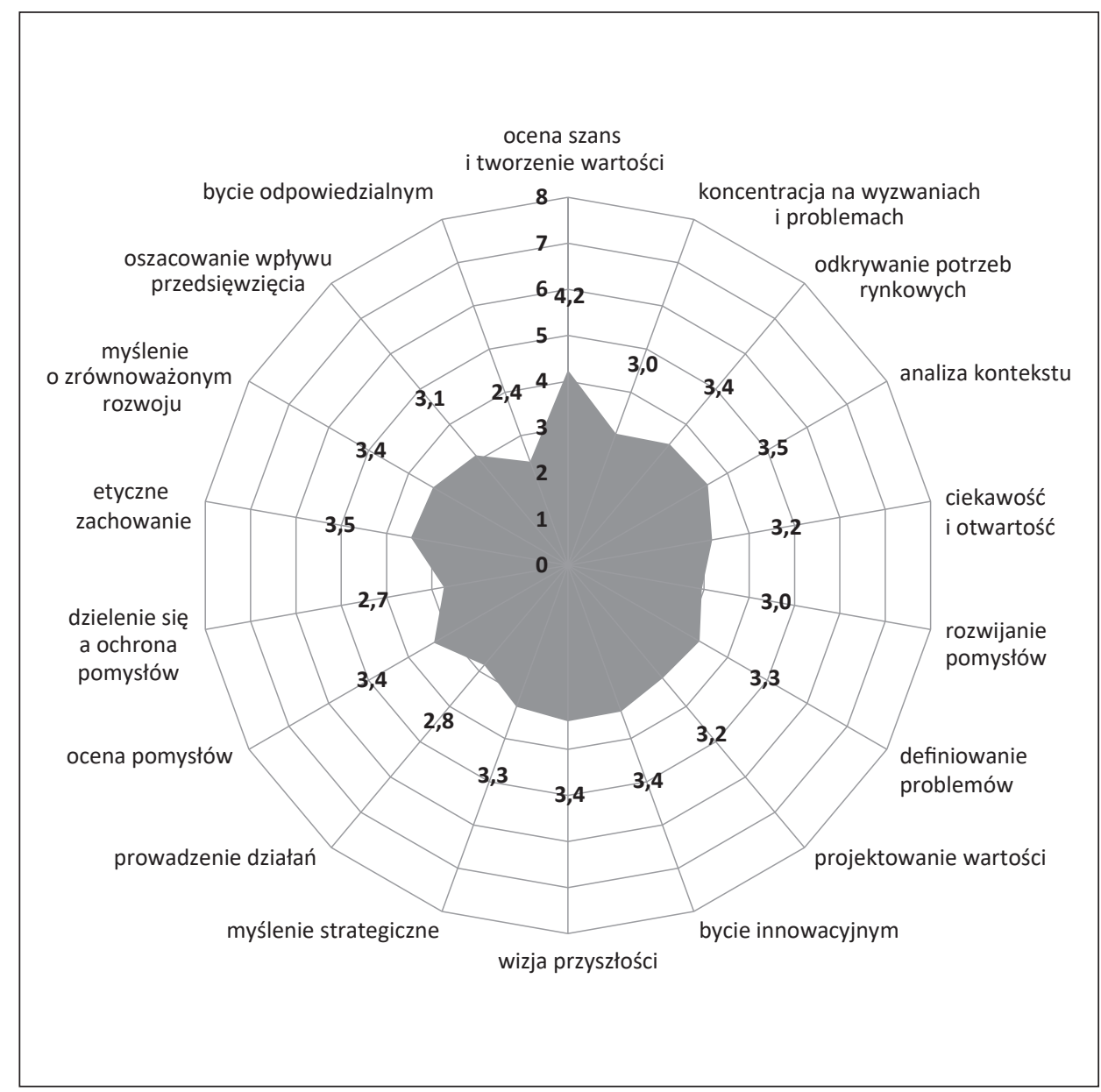

Źródło: opracowanie własne na podstawie badań 
W celu identyfikacji cech statystycznie istotnie różnicujących badaną zbiorowość wykorzystano korelację rangową Spearmana (Rho), która może być stosowana do opisu siły korelacji dwóch cech, gdy cechy te mają charakter jakościowy, pozwalający na uporządkowanie wartości ze względu na siłę tej cechy. W przeprowadzonych badaniach wartości można uporządkować według poziomów zaawansowania w dokonanej ocenie kompetencji. Cechom, czyli poszczególnym kompetencjom cząstkowym, można przypisać rangi od 1 do 8 .

Z badań wynika, iż poziom współczynnika korelacji rang Spearmana wykazuje wyraźną zależność (korelacja niska) i kształtuje się w przedziale 0,3-0,4 dla opisanych poniżej zależności między niektórymi zmiennymi, które charakteryzują kompetencje przedsiębiorcze (dane zawarte $\mathrm{w}$ tabelach: 4, 5, 6), a cechami: demograficznymi, statusu materialnego, miejsca zamieszkania, sytuacji zawodowej oraz długości okresu studiowania i kierunku kształcenia.

Badanych różnicuje w sposób statystycznie istotny status materialny oraz sytuacja zawodowa. Zauważyć można bowiem, iż częściej osoby dobrze oceniające swój status materialny oraz niepracujące deklarują swoje kompetencje na podstawowym poziomie, tj. potrafią jedynie identyfikować problemy wymagające rozwiązania. Natomiast ci, którzy oceniają swój status nieco gorzej („przeciętnie”), a także pracujący w firmach prywatnych deklarują poziom zaawansowany w zakresie koncentracji na wyzwaniach i problemach.

Natomiast wśród oceniających swój status materialny przeciętnie lub niezadowalająco, a także wśród pracujących częściej zdarzały się deklaracje tych kompetencji na najwyższym poziomie (eksperckim). Osoby te w zakresie koncentracji na wyzwaniach i problemach potrafią wskazać możliwości, w których mogą utrzymać przewagę konkurencyjną.

Inną interesującą kompetencją w obszarze kreowania pomysłów i identyfikowania rynkowych możliwości, zróżnicowaną pod względem czasu zdobywania wiedzy (rok studiów), jest kompetencja bycia innowacyjnym.

Wyniki badań pozwalają zauważyć, iż studenci pierwszego roku nieznacznie częściej deklarowali kompetencje bycia innowacyjnym na podstawowym poziomie, podczas gdy studenci trzeciego roku - na poziomie średniozaawansowanym, zaś reprezentanci studiów II stopnia - na poziomie eksperckim. Wyniki te pozwalają przypuszczać, że kształcenie na poziomie wyższym w uczelniach, w których przeprowadzono badanie, wspiera rozwój kompetencji młodzieży w sferze kreatywności i innowacyjności.

W zakresie „bycia odpornym”, czyli umiejętności pokazywania pasji oraz chęci i determinacji w osiąganiu celów, częściej badanych różnicuje sytuacja zawodowa - pracujący dorywczo częściej wykazywali podstawowy poziom kompetencji, zaś pracujący w firmach prywatnych - poziom ekspercki. Biorąc pod uwagę, że aż 29\% badanych pracuje dorywczo podczas studiów, można przypuszczać, iż praca dorywcza (częściej niepozostająca w związku ze studiowanym kierunkiem) przeszkadza w rozwoju kompetencji w zakresie bycia odpornym na presję i wytrwałym w dążeniu do osiągnięcia zdefiniowanych celów.

W drugim obszarze badań kompetencji: „Zasoby” ankietowani ocenili swoją wiarę we własne możliwości, podążanie za aspiracjami, determinację, motywację oraz wykorzystywanie czasu, zasobów materialnych i niematerialnych, rozumienia zagadnień ekonomicznych i finansowych itp. (tabela 5). 


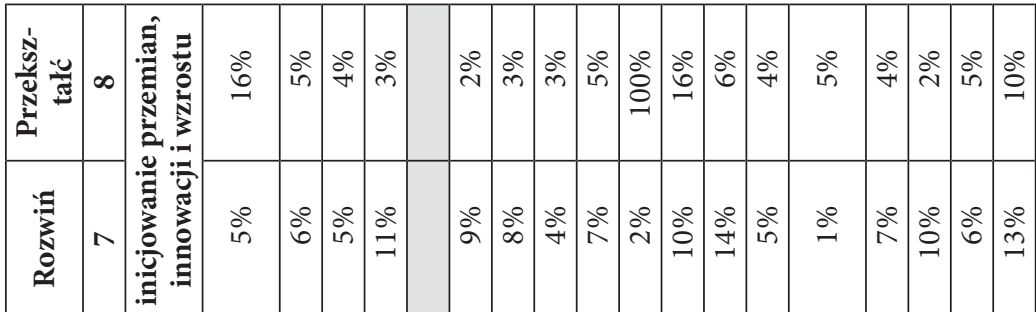

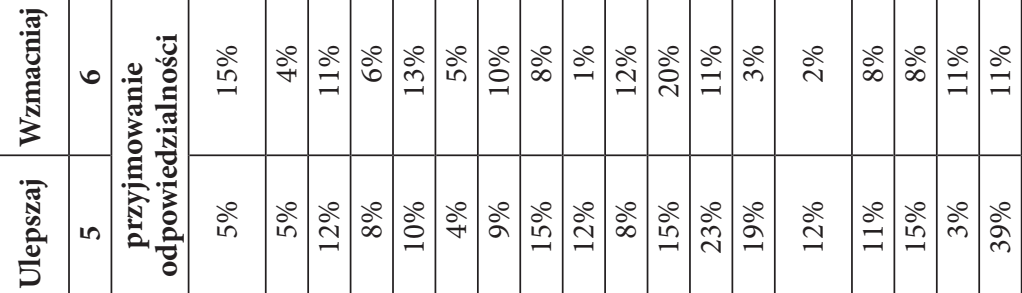

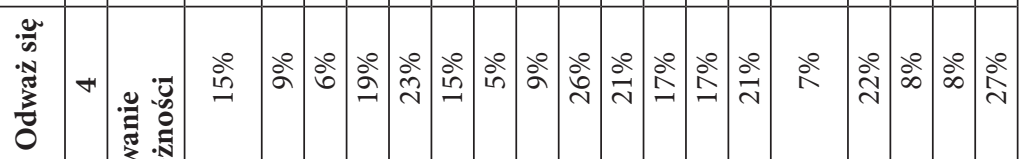

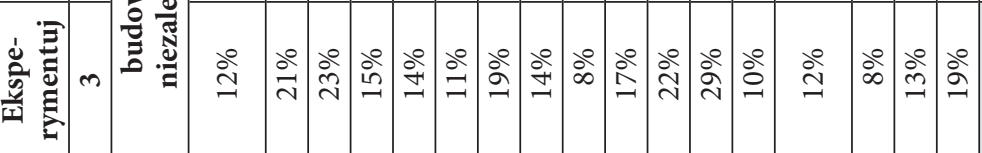

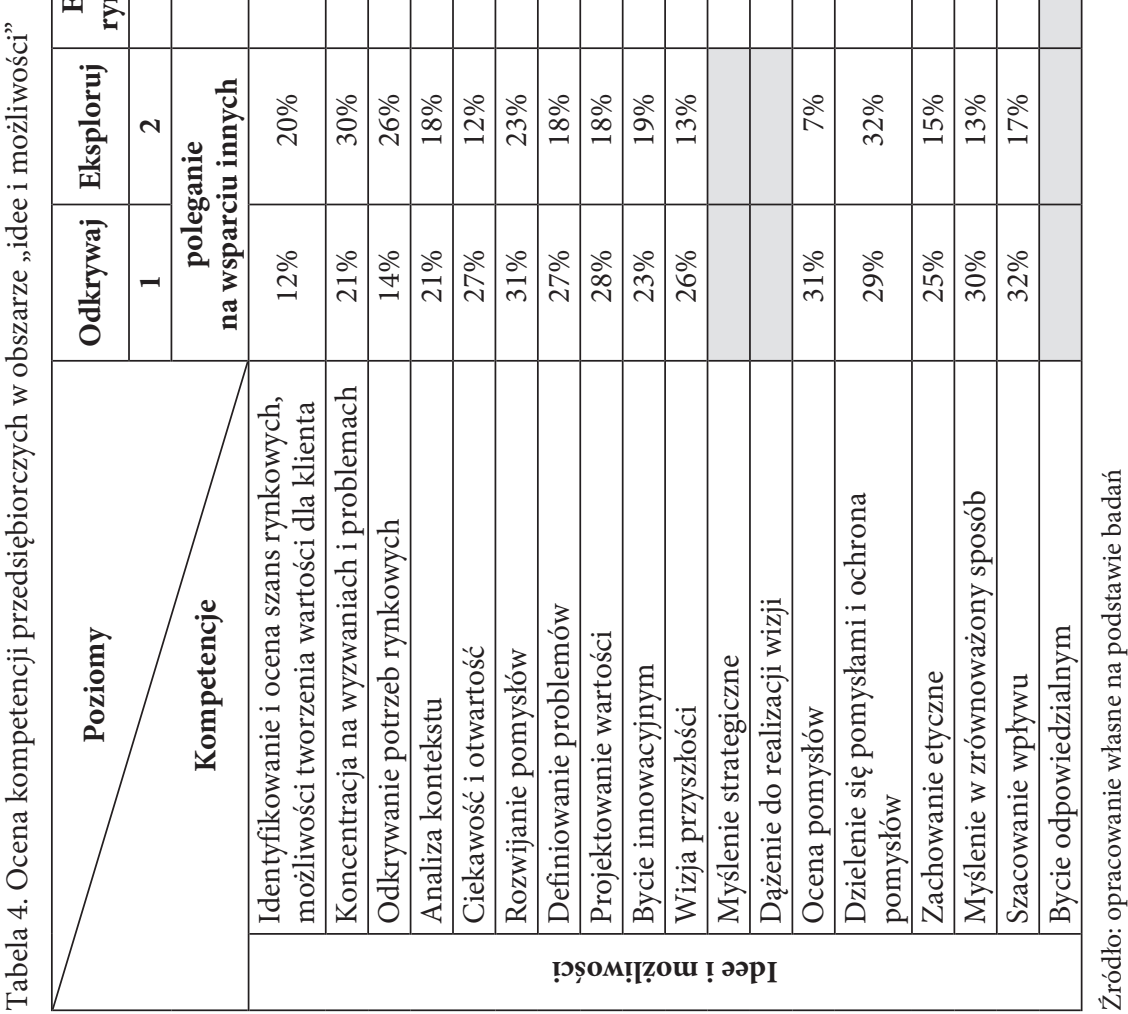




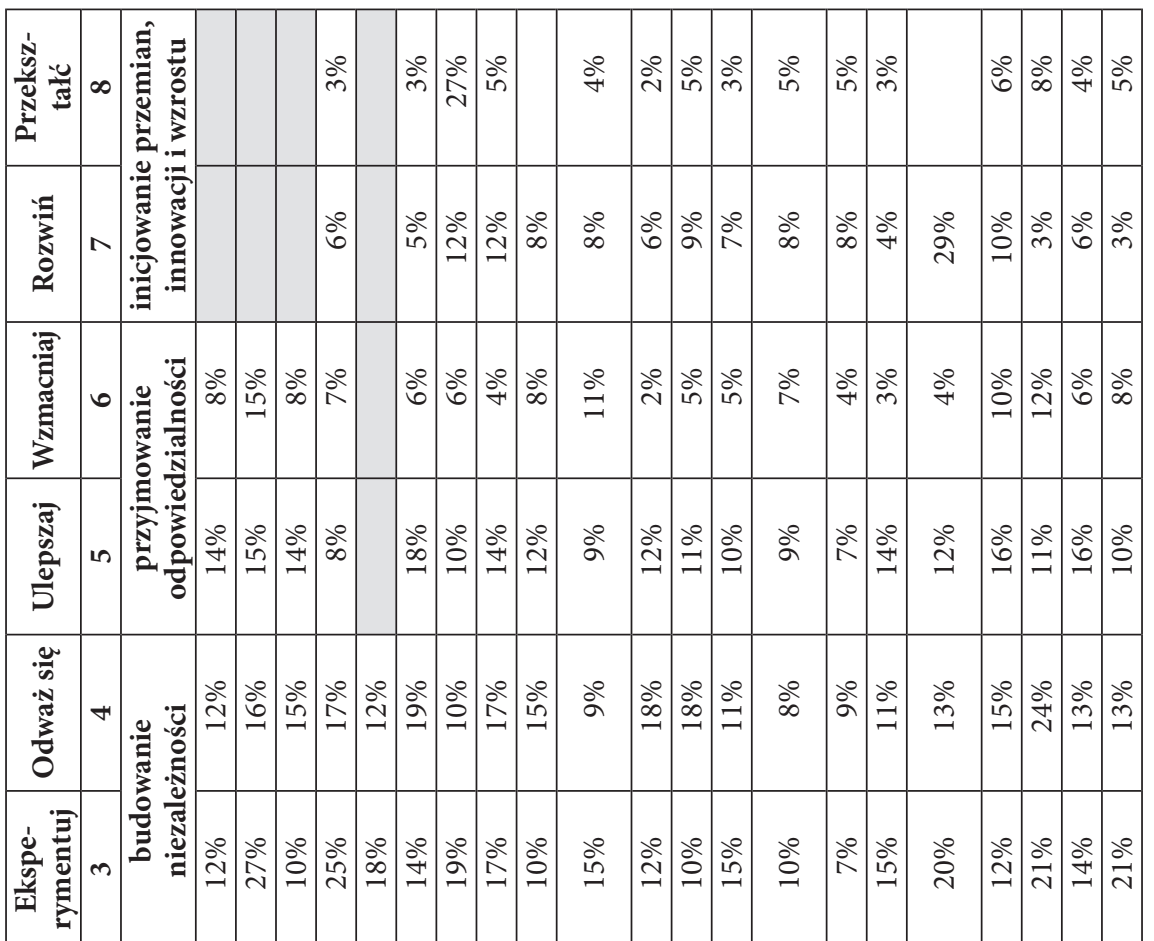

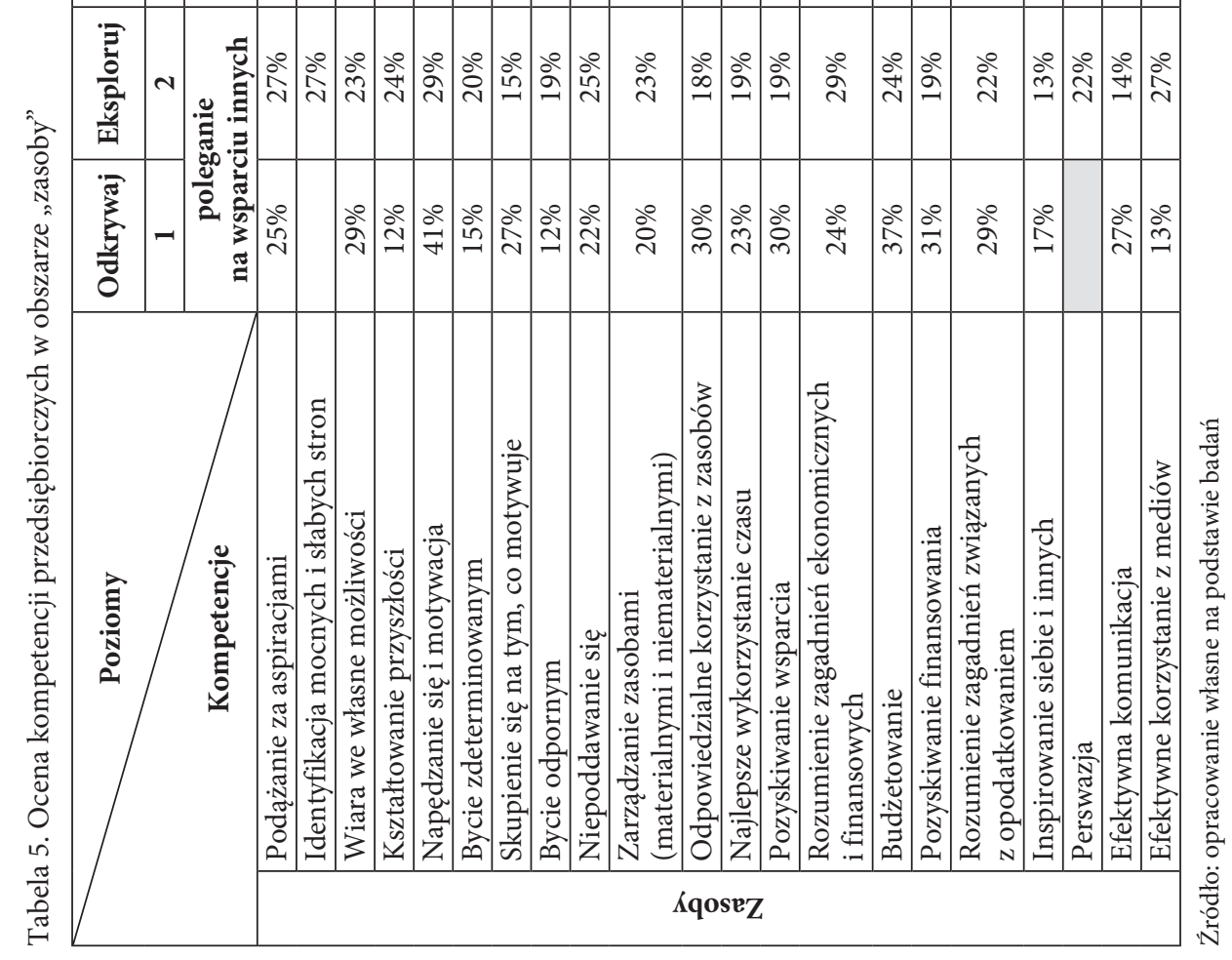




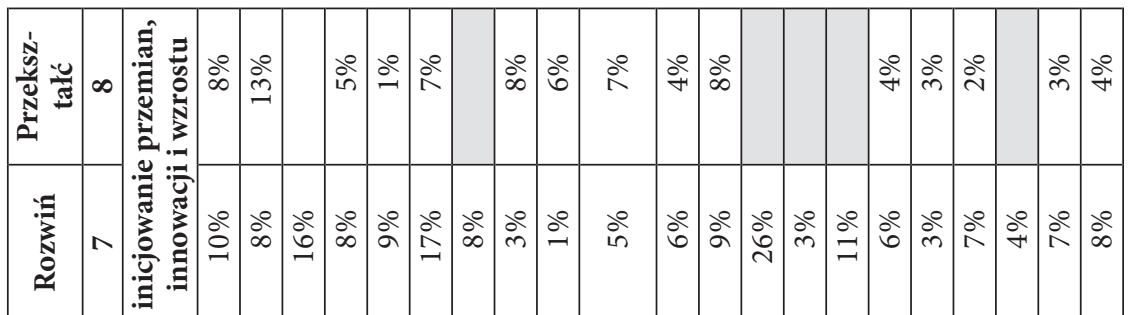

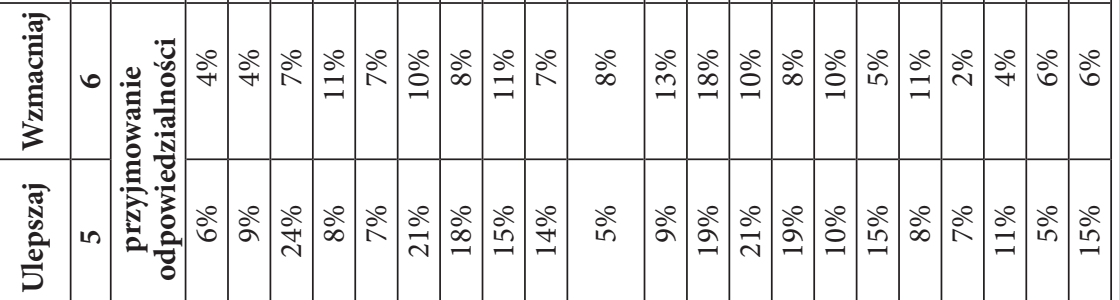

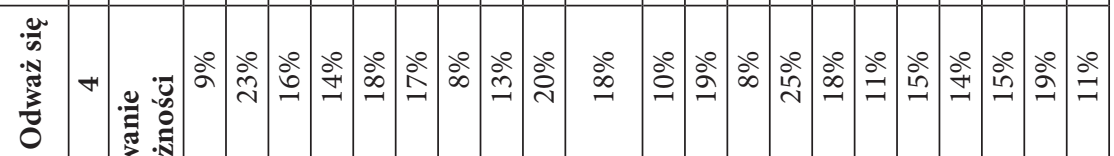

竞

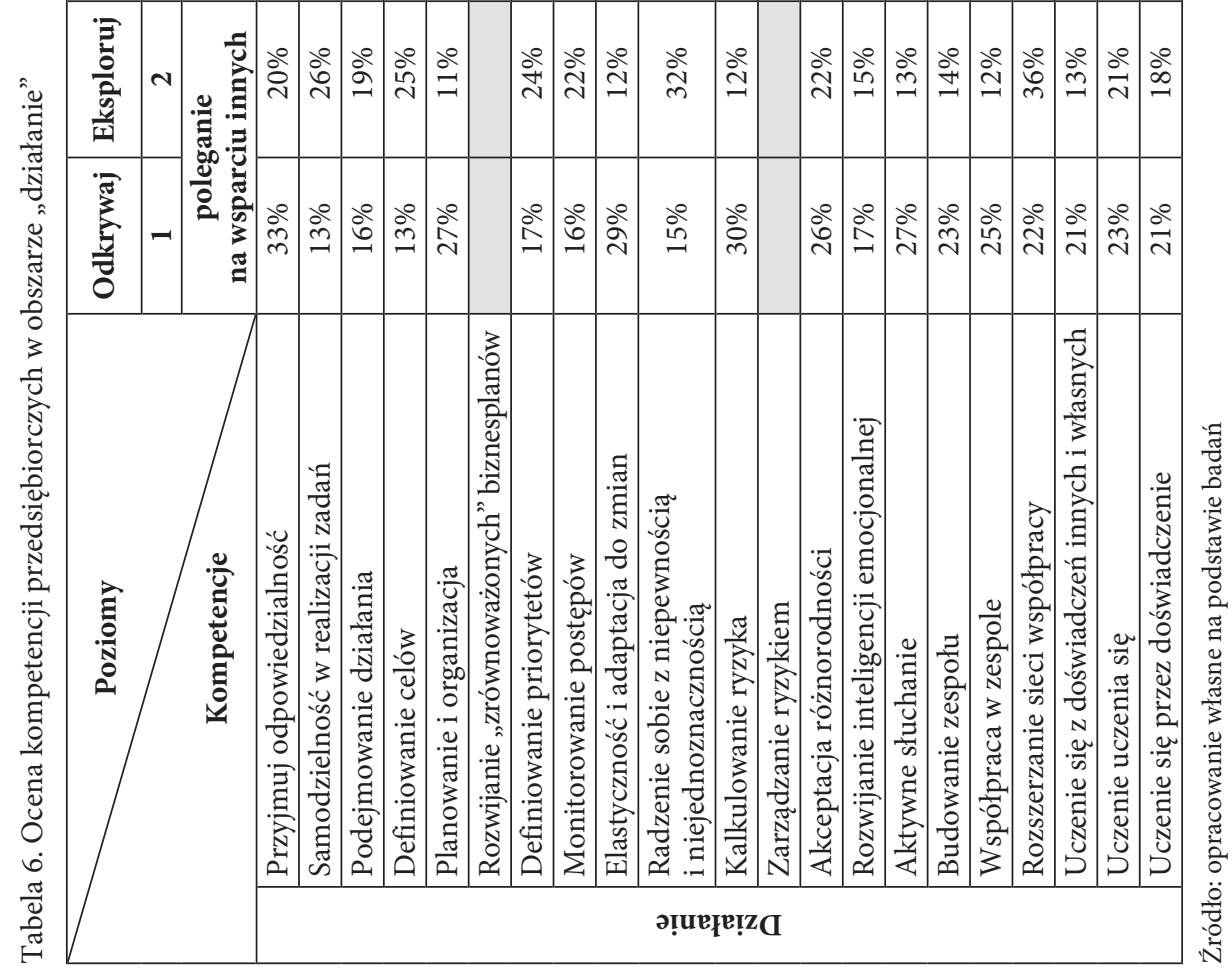


Wyniki badań wskazują, że studenci Uniwersytetu Pedagogicznego nieznacznie częściej deklarowali podstawowe kompetencje w zakresie odpowiedzialności w wykorzystywaniu zasobów (potrafili opisać, w jaki sposób zasoby działają dłużej dzięki recyklingowi i ponownemu użyciu lub naprawie), zaś studenci Uniwersytetu Rzeszowskiego nieco częściej deklarowali poziom zaawansowany, tzw. brali pod uwagę niematerialne koszty korzystania z zasobów przy podejmowaniu decyzji w swoich przedsięwzięciach.

Zbiorcze wyniki analiz w obszarze „działanie” zebrano w tabeli 6. Oceniono tu odpowiedzialność, samodzielność w działaniu, planowanie i organizację, rozwijanie „Zrównoważonych" biznesplanów, rozwijanie inteligencji emocjonalnej itp.

W tym obszarze można zauważyć, iż nieznacznie częściej studenci pierwszego stopnia deklarowali podstawowy poziom kompetencji, tj., że potrafią wskazać, czego nauczyli się w działaniach, zaś studenci drugiego stopnia częściej wskazywali poziom ekspercki, tj., że potrafią uczyć się z mentoringu i ewaluacji działań, które zaprojektowali, aby rozwinąć swoje przedsięwzięcie oraz włączać je w proces uczenia się.

Oprócz zaprezentowanych statystycznie istotnych cech różnicujących badanych, nie zaobserwowano innych istotnych różnic. Autorki planują kontynuować badania w zakresie wykorzystywania metodologii EntreComp do oceny przedsiębiorczych kompetencji młodzieży studiującej na Uniwersytecie Pedagogicznym w Krakowie oraz Uniwersytecie Rzeszowskim.

\section{Podsumowanie}

„Człowiek przedsiębiorczy nie boi się trudności, podejmowania nowych zadań, nie załamuje się niepowodzeniami, jest niezależny i elastyczny, otwarty na zdobywanie wiedzy, nowych umiejętności oraz na otoczenie, potrafi cieszyć się z sukcesów, ma zdolność do empatii, jest gotowy do współpracy z innymi ludźmi i postępuje zgodnie z wartościami etycznymi” (Borowiec, Rachwał, 2011: 323). Przedsiębiorczość w takim rozumieniu „jest odzwierciedlana w aktywnym i twórczym dążeniu do doskonalenia istniejących rzeczy, ale też w podejmowaniu nowych działań" (Borgiasz, 2017: 185). Wielowymiarowość i wielowątkowość zagadnień związanych z przedsiębiorczością, jako fenomen społeczno-gospodarczy (Cieślik, 2014), zróżnicowanie poglądów i perspektyw patrzenia na to zjawisko, powoduje, że badacze ciągle poszukują adekwatnych sposobów „uprawiania” nauki o przedsiębiorczości i najbardziej adekwatnej metody służącej eksploracji tego obszaru (Baran, Bąk, 2016).

W ostatnich latach podejmowany jest ogromny wysiłek finansowy i organizacyjny w celu zwiększenia skali edukacji przedsiębiorczej (Lans i in., 2008). Stymulowanie postaw i inicjatyw przedsiębiorczych wśród studentów na uczelniach wyższych, przekładające się na wzrost poziomu omawianych kompetencji przedsiębiorczych, wymaga stałego doskonalenia tego procesu (por. Czyżewska, 2018: 34).

Autorki artykułu zdiagnozowały poziom kompetencji przedsiębiorczych studentów wybranych uczelni wyższych, wykorzystując nowe narzędzie badawcze, którym jest metodologia EntreComp, oraz zidentyfikowały występujące zależności w poziomie kompetencji przedsiębiorczych różnicujących badanych studentów. Uzyskane wyniki badań pokazują, iż z reguły poziom kompetencji przedsiębiorczych oceniany jest dość nisko, co skłania do przemyśleń dotyczących stosowanych metod kształcenia przedsiębiorczości i ich efektywności. Rozważania dotyczące zasadniczego pytania, czy przedsiębiorcą trzeba 
się urodzić, czy też można potrzebne kompetencje nabyć i uzupełnić w procesie edukacji, nadal pozostaje aktualne, a udzielenie odpowiedzi wymaga pogłębionych badań, cyklicznego ich powtarzania, jak również rozszerzenia badanej populacji.

\section{Literatura}

References

Andrzejczak, A. (red.). (2008). Przedsiębiorczość w edukacji. Poznań: Wydawnictwo AE w Poznaniu.

Baran, G., Bąk, J. (2016). Przedsiębiorczość jako proces stawania się. Przedsiębiorczość Międzynarodowa, 2(1), 83-98.

Bieniok, H. (2016). Przedsiębiorczość i innowacyjność źródłem sukcesu osobistego i firmy. Zeszyty Naukowe Uniwersytetu Ekonomicznego w Katowicach, 278, 157-168.

Bojewska, B. (2002). Przedsiębiorczość w zarządzaniu i rozwoju małych i średnich przedsiębiorstw. W: M. Strużycki (red.), Zarządzanie matym i średnim przedsiębiorstwem. Uwarunkowania europejskie. Warszawa: Difin.

Borgiasz, M. (2017). Kompetencje przedsiębiorcze - ich rola i znaczenie w pracy współczesnego nauczyciela. Szkoła - Zawód - Praca, 14, 184-201.

Borowiec, M., Rachwał, T. (2011). Kształtowanie postaw przedsiębiorczych na lekcjach geografii wyzwaniem edukacyjnym w procesach globalizacji. Przedsiębiorczość - Edukacja, 7, 321-332.

Boyatzis, R.E. (1982). The Competent Manager: A Model for Effective Performance. New York: John Wiley \& Sons.

Boyles, T. (2012). 21 $1^{\text {st }}$ Century Knowledge, Skills, and Abilities and Entrepreneurial Competencies: A Model for Undergraduate Entrepreneurship Education. Journal of Entrepreneurship Education, $15,41-55$.

Cieślik, J. (2014). Przedsiębiorczość polityka rozwój. Warszawa: Wydawnictwo Akademickie Sedno.

Czyżewska, M. (2018). Uwarunkowania rozwoju przedsiębiorczości studenckiej na podstawie badań empirycznych. Studia i Prace Kolegium Zarządzania i Finansów, 160, 29-44.

Drucker, P.F. (1992). Innowacja i przedsiębiorczość. Praktyka i zasady. Warszawa: PWE.

EntreComp. (2019, 5 października). The Entrepreneurship Competence Framework. Pozyskano z: http:// publications.jrc.ec.europa.eu/repository/bitstream/JRC101581/lfna27939enn.pdf

Glinka, B., Gudkova, S. (2011). Przedsiębiorczość. Warszawa: Wolters Kluwer.

Kapusta, F. (2006). Przedsiębiorczość. Teoria i praktyka. Poznań, Wrocław: Forum Naukowe: Passat.

Komisja Europejska. (2020, 10 marca). EntreComp: Ramy kompetencji w zakresie przedsiębiorczości. Pozyskano z: https://ec.europa.eu/jrc/en/entrecomp/policy-background-and-methodology

Lans, T., Hulsink, W., Baert, H., Mulder, M. (2008). Entrepreneurship Education and Training in a Small Business Context: Insights from the Competence-Based Approach. Journal of Enterprising Culture, 16(4), 363-383.

Mitchelmore, S., Rowley, J. (2010). Entrepreneurial competencies: a literature review and development agenda. International Journal of Entrepreneurial Behaviour \& Research, 16(2), 92-111.

Moczydłowska, J. (2008). Zarządzanie kompetencjami zawodowymi a motywowanie pracowników. Warszawa: Difin.

Moczydłowska, J. (2009). Kompetencje przedsiębiorcze mikroprzedsiębiorcy. Zeszyty Naukowe Uniwersytetu Szczecińskiego. Ekonomiczne Problemy Ustug, 540(34), 388-394.

Piróg, D. (2015). Kompetencje z zakresu przedsiębiorczości: rozważania teoretyczne i ich ilustracje w obszarze szkolnictwa wyżzzego. Przedsiębiorczość - Edukacja, 11, 364-376.

Rachwał, T. (2004). Cele i treści kształcenia przedsiębiorczości w szkołach ponadgimnazjalnych. W: J. Brdulak, M. Kulikowski (red.), Przedsiębiorczość stymulatorem rozwoju gospodarczego. Warszawa: Instytut Wiedzy, 263-270.

Wach, K. (2013). Edukacja na rzecz przedsiębiorczości wobec współczesnych wyzwań cywilizacyjno-gospodarczych. Przedsiębiorczość - Edukacja, 8, 246-257. 
Wach, K. (2015). Przedsiębiorczość jako czynnik rozwoju społeczno-gospodarczego: przegląd literatury. Przedsiębiorczość - Edukacja, 11, 24-36.

Wiatrak, A.P. (2003). Pojęcie przedsiębiorczości, jej cele i rodzaje. W: K. Jaremczuk (red.), Uwarunkowania rozwoju przedsiębiorczości - szanse i zagrożenia. Tarnobrzeg: Wydawnictwo PWSZ.

Wyrzykowska, B. (2012). Przedsiębiorczość intelektualna jako kompetencja współczesnego menedżera. Zeszyty Naukowe SGGW. Ekonomika i Organizacja Gospodarki Żywnościowej, 100, 26-35.

Marta Czyżewska, dr nauk ekonomicznych w zakresie ekonomii. Adiunkt w Katedrze Ekonomii i Polityki Gospodarczej w Instytucie Prawa, Administracji i Ekonomii Uniwersytetu Pedagogicznego w Krakowie. Jej badania skupiają się wokół determinant innowacyjności i przedsiębiorczości jako kluczowych czynników warunkujących rozwój gospodarek. Jest autorką lub współautorką artykułów i książek na temat startupów, venture capital, innowacyjności i przedsiębiorczości.

Marta Czyżewska, PhD in Economics, assistant professor in the Department of Economics and Economic Policy, The Institute of Law, Administration and Economics at the Pedagogical University of Krakow. Her research focuses on determinants of innovativeness and entrepreneurship as key factors underlying economies development. Author and co-author of articles and books on startups, venture capital, innovativeness and entrepreneurship.

ORCID: https://orcid.org/0000-0001-6709-6842

\title{
Adres/Address:
}

Uniwersytet Pedagogiczny im. Komisji Edukacji Narodowej w Krakowie

Instytut Prawa, Administracji i Ekonomii

Katedra Ekonomii i Polityki Gospodarczej

ul. Podchorążych 2/234

30-084 Kraków, Polska

e-mail: marta.czyzewska@up.krakow.pl

Karolina Kozioł, mgr ekonomii, asystent, Uniwersytet Rzeszowski, Instytut Ekonomii i Finansów Kolegium Nauk Społecznych, Katedra Ekonomiki i Zarządzania. Absolwentka Wydziału Ekonomii, od kilku lat związana ze środowiskiem startupowym na Wydziale Ekonomii Uniwersytetu Rzeszowskiego. Jej główne zainteresowania naukowe koncentrują się wokół rozwoju oraz uwarunkowań przedsiębiorczości, czynników warunkujących powstawanie i wzrost startupów oraz form ich finansowania.

Karolina Koziol, MA in Economics, assistant, University of Rzeszów, Institute of Economics and Finance, College of Social Sciences, Department of Economics and Management. A graduate of the Faculty of Economics, for several years associated with the startup environment at the Faculty of Economics of the University of Rzeszów. The main research interests focus on the development and conditions of entrepreneurship, factors conditioning the creation and growth of startups, and forms of financing them.

ORCID: https://orcid.org/0000-0002-2195-6373

\author{
Adres/Address: \\ Uniwersytet Rzeszowski \\ Instytut Ekonomii i Finansów \\ Kolegium Nauk Społecznych \\ Katedra Ekonomiki i Zarządzania \\ ul. M. Ćwiklińskiej 2 \\ 35-601 Rzeszów, Polska \\ e-mail: kakoziol@ur.edu.pl
}

